\title{
The Monetary Instrument Matters
}

\author{
William T. Gavin, Benjamin D. Keen, and Michael R. Pakko
}

\begin{abstract}
This paper revisits the debate over the money supply versus the interest rate as the instrument of monetary policy. Using a dynamic stochastic general equilibrium framework, the authors examine the effects of alternative monetary policy rules on inflation persistence, the information content of monetary data, and real variables. They show that inflation persistence and the variability of inflation relative to money growth depend on whether the central bank follows a money growth rule or an interest rate rule. With a money growth rule, inflation is not persistent and the price level is much more volatile than the money supply. Those counterfactual implications are eliminated by the use of interest rate rules whether prices are sticky or not. A central bank's use of interest rate rules, however, obscures the information content of monetary aggregates and also leads to subtle problems for econometricians trying to estimate money demand functions or to identify shocks to the trend and cycle components of the money stock.
\end{abstract}

Federal Reserve Bank of St. Louis Review, September/October 2005, 87(5), pp. 633-58.

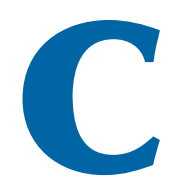

entral banks around the world have long settled on the use of interest rates as instruments to implement monetary policy; but, until recently, there was no sound theory supporting this choice. The intuition for why interest rate rules dominate is straightforward in a world with sticky prices and interest-elastic money demand (see boxed insert). When the demand for real money balances is interest elastic, any shock that affects the path for expected inflation or the real interest rate causes money demand to shift. When the central bank follows a money growth rule, this shift causes the price level to jump. If price adjustment is costly, this jumping can create real distortions. When the central bank follows an interest rate rule, on the other hand, the money stock is endogenous and absorbs the adjustment. The central bank can accommodate this jump in the money stock almost instantaneously and with little cost.
This article explains the theory behind this intuition by comparing and contrasting the properties of four monetary general equilibrium models. The four models differ along two dimensions: the monetary authority's policy rule and the nature of price adjustments. We examine two monetary policy rules-an exogenous money growth rule and an interest rate rule based on Taylor (1993) and two price adjustment mechanisms-flexible prices found in a typical real business cycle (RBC) model and sticky prices found in a typical New Keynesian model. The closest work to this article is Kim (2003), which looks at how the cyclical nature of the real economy depends on the specification of the policy rule and the form of the nominal frictions. The author concludes that getting the policy rule right is at least as important as getting the nominal frictions right. Our paper emphasizes the behavior of money and prices, but also reports results for real variables that are consistent with Kim's findings.

William T. Gavin is a vice president and economist and Michael R. Pakko is a senior economist at the Federal Reserve Bank of St. Louis. Benjamin D. Keen is an assistant professor of economics at the University of Oklahoma. The authors thank Dick Anderson and Ed Nelson for helpful comments. Michelle Armesto provided research assistance.

(C) 2005, The Federal Reserve Bank of St. Louis. Articles may be reprinted, reproduced, published, distributed, displayed, and transmitted in their entirety if copyright notice, author name(s), and full citation are included. Abstracts, synopses, and other derivative works may be made only with prior written permission of the Federal Reserve Bank of St. Louis. 


\section{MONEY DEMAND AND INTEREST RATE RULES}

The intuition for the difference between an interest rate and a monetary aggregate instrument can be gleaned from the analysis of money demand in Friedman (1969). The demand for real money balances is a function of a scale variable, such as income, and an opportunity cost variable, such as the nominal interest rate, such that $M_{t}^{D} / P_{t}=H\left(\stackrel{+}{Y}_{t}, \bar{R}_{t}\right)$. Panel A in the accompanying figure is based on Figure 3 from Friedman's illustration of the response of money demand and the price level following the central bank's surprise decision to permanently raise the money growth trend (inflation) from zero to a positive number-that is, 2 percent in Panel A. The money supply and the price level are indexed to 100 and remain fixed before the policy change. With the 2 percent rise of inflation, the nominal interest rate rises by 2 percent and the demand for money drops immediately. Because the central bank has exogenously fixed the money growth rate, the price level must rise to accommodate the fall in real balances. In an economy where the long-run expected inflation trend is subject to shocks, the inflation rate is highly variable relative to the money growth rate.

Panel B illustrates what happens if the central bank uses the interest rate as the monetary policy instrument. In that case, the credible announcement of 2 percent inflation requires raising the nominal interest rate target by 2 percent. The increase also leads to an immediate drop in the demand for real money balances. With a nominal interest rate rule, however, the money supply is endogenous and inflation is fixed by the policy rule. It is the money stock, rather than the price level, that responds by shifting downward to clear the money market. Hence, in an economy with stochastic inflation and an interest rate rule for monetary policy, the money growth rate is much more variable than the inflation rate. That result is consistent with our observations from modern economies where central banks generally use the nominal interest rate to implement policy.

\section{Figure B1}

\section{Monetary Policy Rules and a Change in the Inflation Target}

\section{A. Money Growth Rule*}

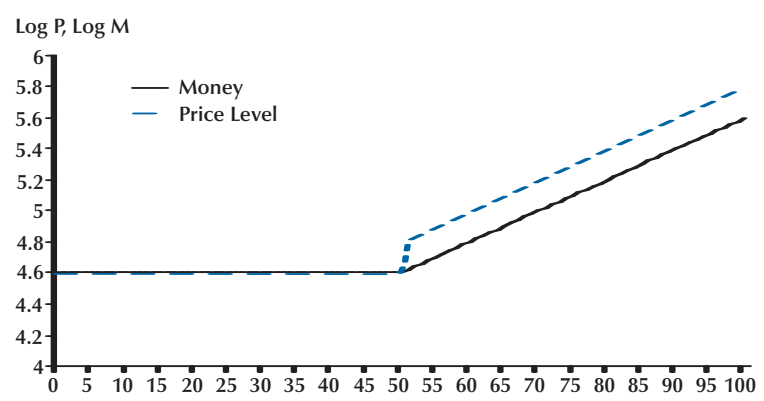

\section{B. Interest Rate Rule*}

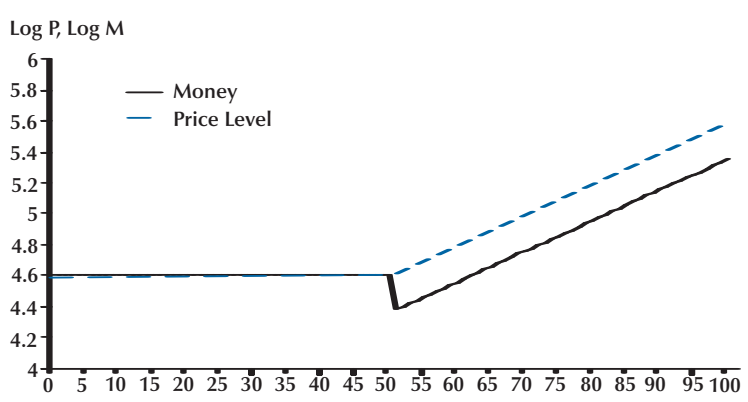

*There is a shift from 0 to 2 percent in the inflation objective in period 50. 
Early dynamic stochastic general equilibrium models that featured money as the policy instrument also included flexible prices-and hence implied small effects of monetary shocks on real variables and unrealistically high price-level variability with low inflation persistence; examples include Cooley and Hansen (1989, 1995), Lucas (1990), Fuerst (1992), and Christiano and Eichenbaum (1992). ${ }^{1}$ Later, models with sticky prices came to dominate the literature; Cho and Cooley (1995), Kimball (1995), King and Wolman (1996), and Yun (1996) are representative of this approach. $^{2}$

Kimball (1995), for example, examined a sticky-price model that assumed a constant velocity of money and an exogenous money supply rule. This article demonstrates that two distinct elements omitted from Kimball's model are crucial for understanding price dynamics. The first is an interest-sensitive money demand function, and the second is a monetary policy reaction function based on an interest rate rule. King and Wolman (1996) present a model with a shopping-time role for money demand that is interest elastic, but most of their analysis assumes that the central bank either controls inflation directly or follows an exogenous money growth rule. They include only a very brief analysis of money growth rules versus interest rate rules.

We extend the methodology of King and Wolman (1996) to analyze more thoroughly the important distinctions between flexible-price and sticky-price models on the one hand and between interest rate rules and money supply rules on the other. Even though central banks do not use money growth rules in practice, we compare that regime to interest rate regimes because much of our conventional wisdom about money and monetary policy comes from analysis using models with money growth rules. We also emphasize a distinction between the steady-state inflation

1 See Dittmar, Gavin, and Kydland (2005) and Dressler (2003) for recent examples with flexible-price models with interest rate rules. Ireland (2003) examines the role of policy in estimated versions of both flexible- and sticky-price models.

2 See also influential papers by Ireland (1996), Rotemberg and Woodford (1997), and McCallum and Nelson (1999). This basic sticky-price model is developed rigorously by Woodford (2003, Chap. 3). rate and the inflation target. Historically, most central banks have not had constant inflation targets, but their targets evolve over time. Here the expected inflation target converges to the steady state in the long run, but it can deviate for a considerable period. Consequently, we consider two types of policy shocks: a highly persistent inflation target shock and a relatively short-lived liquidity shock.

\section{THE MODEL}

In this model framework, agents are infinitely lived. Households get utility from consumption and leisure but need to spend time shopping for consumption goods; they can reduce the shopping time for a given level of consumption by holding higher money balances. The interest elasticity of money demand is a key parameter for determining the nature of inflation dynamics. Households consume a composite good that is a combination of outputs from monopolistically competitive firms. Sticky prices are introduced using a Calvo (1983) specification that allows for the possibility of perfect price flexibility as a nested special case. ${ }^{3}$ Thus, it is straightforward to hold all other model features constant when comparing sticky-price and flexible-price specifications. Monetary policy is conducted through lump-sum monetary transfers that are determined by the central bank's monetary policy rule. Our focus is on the differences implied by policy rules that use the shortterm interest rate as an instrument versus those that target money growth directly.

\section{Households}

Each period, households maximize the discounted present value of the expected utility they get from consumption and leisure:

$$
U=E_{0} \sum_{t=0}^{\infty} \beta^{t} u\left(c_{t}, l_{t}\right),
$$

where $\beta$ is the household's discount factor, $c_{t}$ is the consumption bundle, and $l_{t}$ is leisure time.

\footnotetext{
3 The version with Calvo-style pricing and a money growth rule was presented by Keen (2004). Appendix A provides complete details of our model specification and solution procedures.
} 
The momentary utility function is assumed to take the form

$$
u\left(c_{t}, l_{t}\right)=\ln \left(c_{t}\right)+\chi \frac{l_{t}^{1-\sigma_{1}}}{1-\sigma_{1}},
$$

where the values of the preference parameters $\sigma_{1}$ and $\chi$ are positive.

The household maximizes (1) subject to a budget constraint

$$
\begin{aligned}
& P_{t} c_{t}+P_{t} i_{t}+M_{t}+B_{t} \\
& =P_{t} w_{t} n_{t}+P_{t} q_{t} k_{t}+D_{t}+M_{t-1}+R_{t-1} B_{t-1}+T_{t},
\end{aligned}
$$

where $P_{t}$ is the nominal goods price; $i_{t}$ is investment; $k_{t}$ is the capital stock, which evolves following the capital accumulation process, $k_{t+1}=i_{t}+$ $(1-\delta) k_{t}$, and depreciates at rate $\delta . M_{t}$ and $B_{t}$ are stocks of money and bonds, $w_{t}$ is the real wage rate, $q_{t}$ is the real rental price of capital, and $R_{t-1}$ is the gross nominal interest rate on bonds purchased at time $t-1$. The household also receives monetary transfers, $T_{t}$, and distributed profits from the goods-producing sector, $D_{t}$.

The household also faces a time constraint, which specifies that total time (normalized to unity) can be allocated to leisure, labor, and time spent in transactions-related activities, $s_{t}$ :

$$
l_{t}+n_{t}+s_{t}=1 .
$$

The amount of time households spend shopping, $s_{t}$, can be reduced by holding larger money balances relative to nominal consumption expenditures:

$$
s_{t}=\zeta\left(\frac{P_{t} c_{t}}{M_{t}}\right)^{\gamma} \text {. }
$$

Money-demand elasticities are determined by the curvature parameter, $\gamma>0$, and $\zeta>0$ is a scale parameter used to calibrate $s$.

As discussed by Lucas (2000), this type of shopping-time specification implies a set of general equilibrium relationships that resemble a standard money-demand function. In particular, after combining some of the first-order conditions from the household's utility maximization problem, optimal real money balances can be expressed as

$$
\frac{M_{t}}{P_{t}}=\left[\frac{\zeta \gamma w_{t} C_{t}^{\gamma}}{\frac{R_{t}-1}{R_{t}}}\right]^{\frac{1}{1+\gamma}} .
$$

With the calibration $\gamma=1$, this implies an interest elasticity of $-1 / 2$. Note also that the real wage rate and consumption spending enter this relationship in such a way that their combined relationship with real money balances is one-for-one; that is, so long as productivity and consumption move together (as they do on the steady-state path), the scale elasticity of this money "demand" function is unity.

\section{Firms}

The composite consumption good is a combination of outputs, $y_{j, t}$, produced in period $t$ by monopolistically competitive firms. Each firm's output comes from a production function,

$$
y_{j, t}=Z_{t} f\left(k_{j, t}, n_{j, t}\right),
$$

where $j$ indicates the number of periods since the firm last adjusted its price, $n_{j, t}$ is the firm's demand for labor, $k_{j, t}$ is the firm's demand for capital, and $Z_{t}$ is an economywide productivity factor. The productivity factor is assumed to follow a stationary autoregressive process,

$$
\ln \left(Z_{t}\right)=\rho_{Z} \ln Z_{t-1}+\left(1-\rho_{Z}\right) \ln (Z)+\varepsilon_{Z t},
$$

where $Z$ is the steady-state value of $Z_{t}$ and $\varepsilon_{Z t}$ is a mean-zero, independently and identically distributed (i.i.d.) shock. Every period, each firm must determine (i) the cost-minimizing combination of $n_{j, t}$ and $k_{j, t}$ given its output level, the real wage rate, $w_{t}$, and the real rental rate of capital, $q_{t}$; and (ii) whether or not it can adjust its price. Sticky prices are introduced using Calvo's (1983) model of random price adjustment. Specifically, the probability that a firm can set a new price, $P_{t}^{*}$, is $\eta$ and the probability that a firm must keep the price that it set $j$ periods ago is $(1-\eta)$.

Each period, firms seek to minimize their costs,

$$
w_{t} n_{j, t}+q_{t} k_{j, t},
$$

subject to the production function (6). Market- 
clearing conditions require that an individual firm's labor and capital demand must sum to the economy aggregates, $n_{t}$ and $k_{t}$. Our goal here is merely to understand the workings of a simple model, so we have omitted capital adjustment and other frictions that are often included in this type of model.

Cost minimization by households yields the following demand equation facing each firm:

$$
y_{j, t}=\left(\frac{P_{t-j}^{*}}{P_{t}}\right)^{-\varepsilon} y_{t},
$$

where $-\varepsilon$ is the price elasticity of demand. Aggregate output, $y_{t}$, is given by

$$
y_{t}=\left[\sum_{j=0}^{\infty} \eta(1-\eta)^{j} y_{j, t}^{(\varepsilon-1) / \varepsilon}\right]^{\varepsilon /(\varepsilon-1)},
$$

and the aggregate price level is a nonlinear combination of current and past prices,

$$
P_{t}=\left[\sum_{j=0}^{\infty} \eta(1-\eta)^{j} P_{t-j}^{*}(1-\varepsilon)\right]^{1 /(1-\varepsilon)} .
$$

Appendix A describes in more detail the implications of this pricing structure for the evolution of the aggregate price level.

\section{Policy Rules}

Two classes of monetary policy regimes are considered: a regime in which the central bank follows an exogenous money growth rule and a regime with a nominal interest rate rule in which money growth is endogenous. Both policy rules have two sources of disturbance: One is a shock to the inflation target and the other is a shock to the liquidity position. ${ }^{4}$ The shocks are identified only by how long they persist. A shock to the liquidity position is not expected to affect inflation expectations except at very high frequencies. Historical examples of extreme liquidity shocks would be the Fed's responses to the 1987 stock market crash and the September 11th attacks. In contrast, a shock to the inflation target is expected

\footnotetext{
4 Both Ireland (2005) and Kozicki and Tinsley (2003) identify the inflation target shock by assuming that this component has a unit root.
}

to be highly persistent, almost permanent. In our model, we assume that the Fed has full credibility and the inflation target is known.

In the United States today, the Fed does not have an explicit inflation target such that the public could distinguish perfectly between shocks to liquidity and those to the inflation target. (In extreme cases, this is not a problem; but it probably matters for less-extreme cases.) For example, it is not clear whether the Federal Open Market Committee (FOMC) and/or the public have been able to make this distinction during periods of countercyclical policy. ${ }^{5}$

The money growth rule is given as

$$
\Delta \hat{M}_{t}=\hat{\mu}_{t}^{*}+\left(v_{t}-v_{t-1}\right),
$$

where the hat over a variable indicates the percent (or log) deviation from the steady state and $\hat{\mu}_{t}^{*}$ is a stochastic money growth target, $\hat{\mu}_{t}^{*}=\rho_{\mu} \hat{\mu}_{t-1}^{*}+\varepsilon_{\mu t}$, where $\varepsilon_{\mu t}$ is a mean-zero, i.i.d. shock to the nominal growth trend. The second disturbance in (12), $v_{t}$, represents a transitory policy disturbance that follows its own $\mathrm{AR}(1)$ process, $v_{t}=\rho_{v} v_{t-1}+\varepsilon_{v t}$, with a mean-zero, i.i.d. shock, $\varepsilon_{v t}$. Entering the money-growth rule in first differences, the $v$-shock represents a transitory disturbance to the money stock that leaves the long-run growth path unchanged.

In the alternative regime, the central bank operates with a Taylor-type interest rate rule that is given by

$$
\hat{R}_{t}=\hat{\pi}_{t}+\theta_{\pi}\left(\hat{\pi}_{t}-\hat{\pi}_{t}^{*}\right)+\theta_{y} \hat{y}_{t}+u_{t},
$$

where the inflation target follows a stochastic AR(1) process, $\hat{\pi}_{t}^{*}=\rho_{\pi} \hat{\pi}_{t-1}^{*}+\varepsilon_{\pi t}$, and the transitory policy shock, $u_{t}$, follows an AR(1) process, $u_{t}=\rho_{u} u_{t-1}+\varepsilon_{u t}$. Both error processes, $\varepsilon_{\pi t}$ and $\varepsilon_{u t}$, are mean-zero, i.i.d. shocks.

The inflation target shock in equation (13) plays the same role as the money growth shock in (12); both disturbances have a persistent effect on the nominal growth path of the economy. That is, the expected inflation target converges to the steady state in the long run, but the actual target may deviate for long periods. Thus, inflation in period $t$ has three components: the steady-state

5 See Goodfriend (1993) and Erceg and Levin (2003) for analysis of the Fed's credibility. 
inflation rate, the stochastic component of the inflation target (trend), and the transitory component, which is due to other shocks.

It is not clear how to define a common transitory policy shock or liquidity shock under the alternative regimes. We define a transitory policy shock to the money growth rule as a deviation of the money stock that leaves the long-run growth path unchanged. In the case of the interest rate rule, we define a temporary liquidity shock in a straightforward way-as a temporary shock to the short-term interest rate. An expansionary liquidity shock is a positive shock to money growth, $v_{t}$, or a negative shock to the nominal interest rate equation, $u_{t}$. An inflation target shock, $\hat{\pi}_{t}^{*}$, and a nominal interest rate shock, $u_{t}$, have qualitatively identical effects on the model's dynamics. They differ only by a scaling factor and, in our parameterization, by their persistence. ${ }^{6}$

\section{CALIBRATION}

To the extent possible, the parameters are calibrated to generally accepted values for all the experiments. Table 1 shows the baseline calibration used. In the utility function, the value of $\sigma_{1}$ is set at $7 / 9$. The steady-state labor share is 0.3 and shopping time is 1 percent of that value. That calibration implies a labor supply elasticity of real wages approximately equal to $3 .^{7}$ The household discount factor is 0.99 , so that the annual real interest rate is 4 percent. The shopping-time parameter, $\gamma$, is set to unity, implying an interest rate elasticity of money demand equal to -0.5 . The capital share of output is set to 0.33 , and the capital stock is assumed to depreciate at 2.5 percent per quarter. The price elasticity of demand is set equal to 6 , implying a steady-state markup of 20 percent. We set the probability of price adjustment equal to 1 for the flexible-price case and equal to 0.25 for the sticky-price case. For the sticky-price case, this implies that firms change prices on average once per year. The model is

\footnotetext{
6 The scaling is determined by the weight on deviations of inflation from target.

7 The elasticity of labor supply with respect to the real wage equals $((1-\bar{n}-\bar{h}) / \bar{n})\left(1 / \sigma_{1}\right)$.
}

calibrated so that the steady-state inflation rate is zero. ${ }^{8}$

The policy rule is calibrated to match Taylor's (1993) values. The coefficient on the deviation of inflation from target is set at 0.5 , and the response of the interest rate-specified as a quarterly return-to the output gap is 0.125 . Shocks to the nominal growth trend are assumed to be highly persistent, $\rho_{\mu}=\rho_{\pi}=0.95$, whereas the transitory policy shocks have a lower value for their AR parameter, $\rho_{v}=\rho_{u}=0.3$. The shocks to technology are calibrated to be highly persistent, $\rho_{Z}=0.95 .{ }^{9}$

\section{MONETARY POLICY SHOCKS}

As described previously, two types of monetary policy shocks are considered for each policy rule: a shock to the nominal growth trend that displays high persistence (near a random walk) and a transitory policy shock with little persistence. To gain insight about those shocks, we consider their effects separately, comparing their impact on the economy under flexible-price and sticky-price specifications.

\section{Shocks to the Nominal Growth Trend}

Figure 1 illustrates the response of the economy to a persistent money growth shock in a model where the central bank follows a money growth rule. Panels in the left column display the impulse responses produced by the flexibleprice model, and the panels in the right column reflect the responses from the sticky-price model. The top row shows what happens to the price level and the money stock. In both models, the price level jumps immediately after the shock. While the money supply moves identically in both models, the initial price level increase in the sticky-price model is a bit more than half the

\footnotetext{
8 This is necessary to prevent the nonadjusting firms' prices from becoming too far out of line with the flexible-price benchmark. The same model dynamics result if there is positive steady-state inflation and the nonadjusting firms can index prices to rise each period by the steady-state inflation rate.

9 See Appendix A for details about the nonlinear model, the equilibrium, the steady state, and the linear approximation around the steady state that are used to calculate the model dynamics. The solution method is based on King and Watson (1998, 2002).
} 


\section{Table 1}

\section{Baseline Calibration}

\begin{tabular}{|c|c|c|}
\hline & Symbol & Value \\
\hline \multicolumn{3}{|l|}{ Model Parameters } \\
\hline Utility & $\sigma_{1}$ & $7 / 9$ \\
\hline Steady-state market labor share & $n$ & 0.3 \\
\hline Household discount factor & $\beta$ & 0.99 \\
\hline Shopping time & $\gamma$ & 1 \\
\hline Capital share of output & $\alpha$ & 0.33 \\
\hline Depreciation rate & $\delta$ & 0.025 \\
\hline Price elasticity of demand & $\varepsilon$ & 6 \\
\hline Probability of price adjustment & $\eta$ & $\begin{array}{c}0.25 \rightarrow \text { sticky prices } \\
1 \rightarrow \text { flexible prices }\end{array}$ \\
\hline \multicolumn{3}{|l|}{ Policy Reaction } \\
\hline Inflation & $\theta_{p}$ & 0.5 \\
\hline Output & $\theta_{y}$ & 0.125 \\
\hline \multicolumn{3}{|l|}{ Persistence } \\
\hline Technology shock & $\rho_{z}$ & 0.95 \\
\hline Nominal growth shock & $\rho_{\pi}=\rho_{\mu}$ & 0.95 \\
\hline Liquidity shock & $\rho_{v}=\rho_{u}$ & 0.3 \\
\hline \multicolumn{3}{|l|}{ Standard deviation } \\
\hline Technology shock & $\sigma_{z}$ & 0.0075 \\
\hline Nominal growth shock & $\sigma_{\pi}$ & 0.004 \\
\hline
\end{tabular}

14 percent rise in the flexible-price case. The growth rates of money and prices in both models eventually converge back to their steady-state rates, but their levels remain permanently higher.

The second row of Figure 1 shows the impulse responses of the inflation rate to the money growth shock. The inflation spike in period 1 essentially reflects the immediate rise in the price level after the policy shock. In both cases, inflation is persistent following a money growth shock, but the persistence is masked by the surge in prices that occurs contemporaneously with the shock.

The third row shows the responses of the nominal and real interest rates to this shock. Because that initial jump in the price level is unanticipated, it does not affect nominal interest rates. In the flexible-price model, the nominal interest rate increases by about 0.3 percent, which is approximately equal to the expected inflation rate for period 2. The effect on the real rate is near zero in the flexible-price model. With sticky prices, the nominal interest rate rises about 0.75 percent above the steady state, reflecting the higher expected inflation, which is associated with the more gradual response in the price level to the policy shock. The real rate declines for two periods and then gradually returns to the steady state as the effects of the shock dissipate.

The bottom two panels in Figure 1 display the responses of output and hours worked. The higher inflation rate acts as a tax on real money balances, which leads households to spend more time shopping and less time working. With price flexibility, hours worked falls about 0.1 percent below the steady state. With sticky prices and an exogenous money growth rule, neither money nor prices are free to accommodate the jump in money demand. Therefore, the adjustment occurs in real variables. In our sticky-price model, the spike in output is over 80 percent. Given that such a large output response is highly counterfactual, stickyprice models typically incorporate additional 


\section{Figure 1}

\section{Responses to a Persistent Money Growth Shock with a Money Growth Rule}
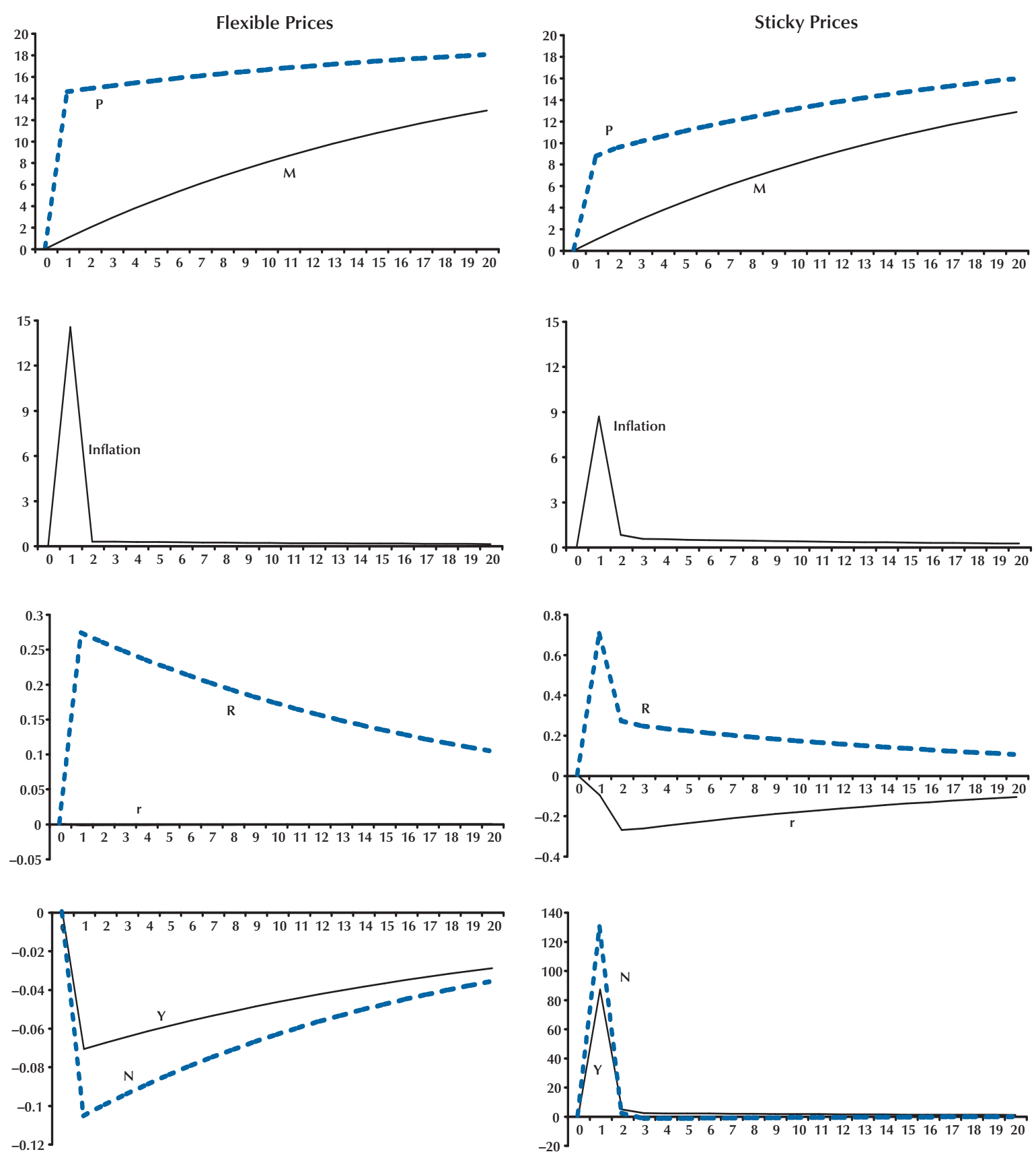

NOTE: $P$, price level; $M$, money supply; $R$, nominal interest rate; $r$, real interest rate; $Y$, output; $N$, hours worked. 
frictions that limit the adjustment of capital and/or labor after a monetary policy shock. ${ }^{10}$

Shifting our analysis to models with an interest rate policy rule, Figure 2 shows how our models respond to an inflation target shock when the Fed is using the Taylor rule. The price level does not jump after the inflation target shock. The higher rate of inflation causes money demand to shift down; but, with an interest rate rule, the money stock declines in order to clear the money market. The size of the fall in the money supply depends on the interest elasticity of money demand. As money demand becomes more interest elastic, the size of the shift needed to clear the money market gets larger. Price level, inflation rate, and interest rate responses are very similar under both the flexible- and sticky-price specifications.

Output responses are much different under the alternative price specifications. In the flexibleprice model, there are small negative effects on output associated with the inflation tax on money holdings. In the sticky-price case, output and hours worked rise, but the effects are much more reasonable than with a money supply rule.

\section{Transitory Policy Shocks}

Figure 3 shows the response of the economy to a transitory money shock. The immediate impact on the price level is smaller in the stickyprice model than in the flexible-price model. This is easiest to see in the second row of panels, which show that the brief spike in inflation is smaller in the sticky-price specification. In neither of these cases, however, does inflation exhibit any measurable persistence. In the third row, we see that the effect on interest rates is small. In the flexible-price case, all of the effect is on the nominal interest rate, which declines temporarily as the price level returns to the original steady-state path. In the sticky-price case, the real return falls by less than in the flexible-price case because the price level never strays far from its steady-state path. Output and hours worked both rise, but the

\footnotetext{
${ }^{10}$ For example, by adding investment adjustment costs to this sticky-price model, one can get reasonable-looking changes in output and larger changes in the real interest rate.
}

size of the effect is an order of magnitude larger with sticky prices.

Note that, for the sticky-price case, we have a pattern of dynamics that corresponds to the textbook description of a liquidity effect. The decline in the nominal interest rate is associated with a corresponding reduction in the real interest rate and a brief surge in output; the relatively large response of output is due to the presence of frictions restricting movement in both the price level and the money supply. Again, the shift in money demand requires large shifts in the real variables.

Figure 4 shows the effect of a transitory liquidity shock when the central bank is using an interest rate rule. In general equilibrium, a 1 percent expansionary (negative) shock actually raises the nominal interest rate by 25 basis points. In both models, we see that the price level rises and the money supply declines. The price increase is large and permanent in the flexible-price model. In the sticky-price case, where only a subset of the firms can react to the shock, its transitory nature causes a smaller adjustment and an eventual decline in the price level below the initial equilibrium path. The third row of panels shows the response of real and nominal interest rates. The nominal rate rises by more in the flexibleprice model because the expected inflation rate in periods 3 and beyond are larger. In the stickyprice model, the real interest rate rises slightly.

The output effect is small and negative in the flexible-price case. In the sticky-price model, a 1 percent shock to the short-term interest rate raises output 5 percent on impact, but the effect dissipates quickly. Note that this type of transitory policy shock-which is standard in the literature on interest rate rules-does not display a textbook liquidity effect under either the sticky-price or flexible-price specification.

\section{Technology Shocks}

The technology shock variable, $z_{t}$, affects the production function directly and therefore engenders a direct effect on output regardless of the nature of the policy rule or whether prices are sticky or flexible. However, the nature of the central bank's policy rule affects the endogenous responses of inputs to the production function- 
Figure 2

\section{Responses to an Inflation Objective Shock with an Interest Rate Rule}
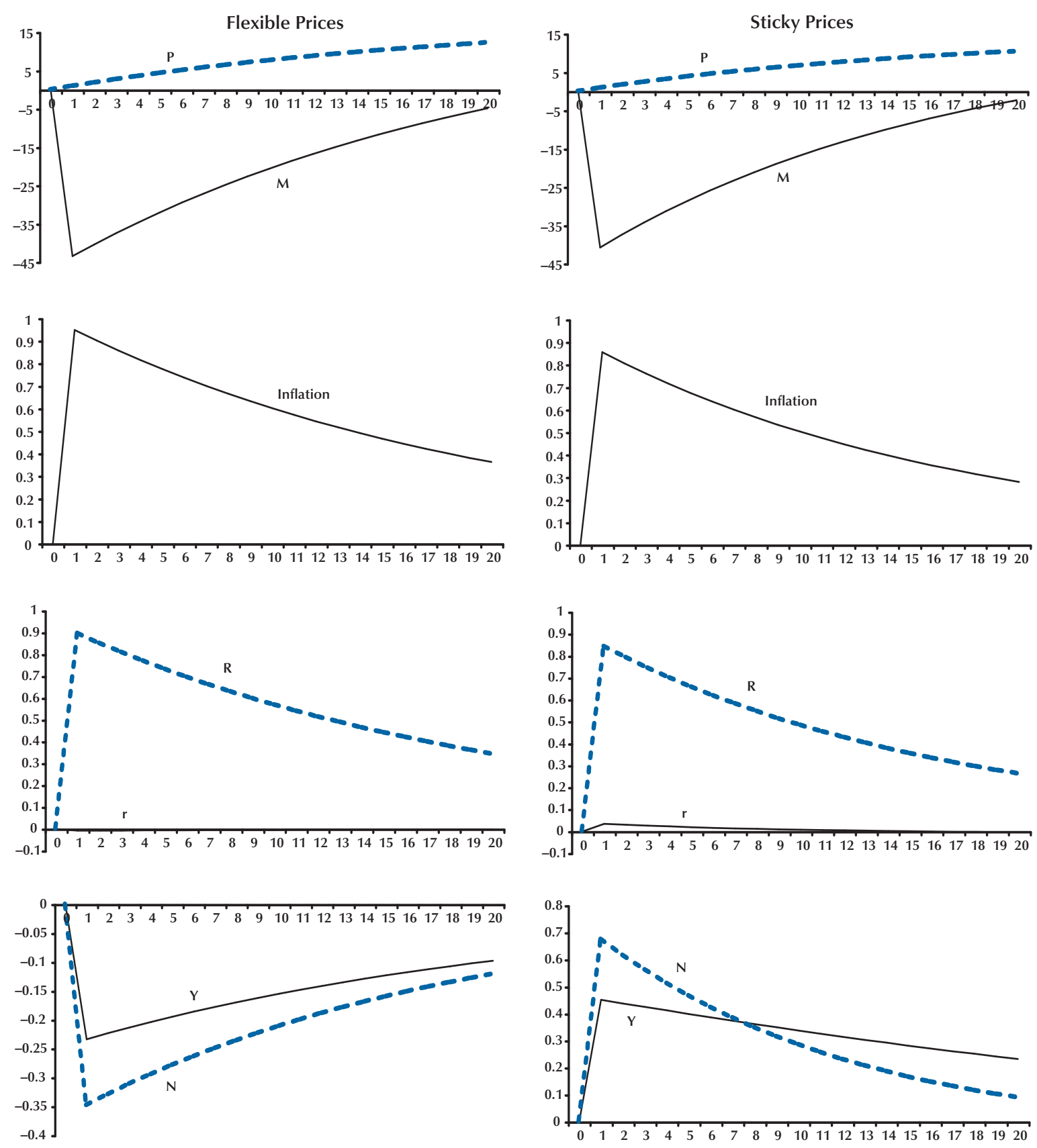


\section{Figure 3}

\section{Responses to a Transitory Policy Shock in a Money Growth Rule}
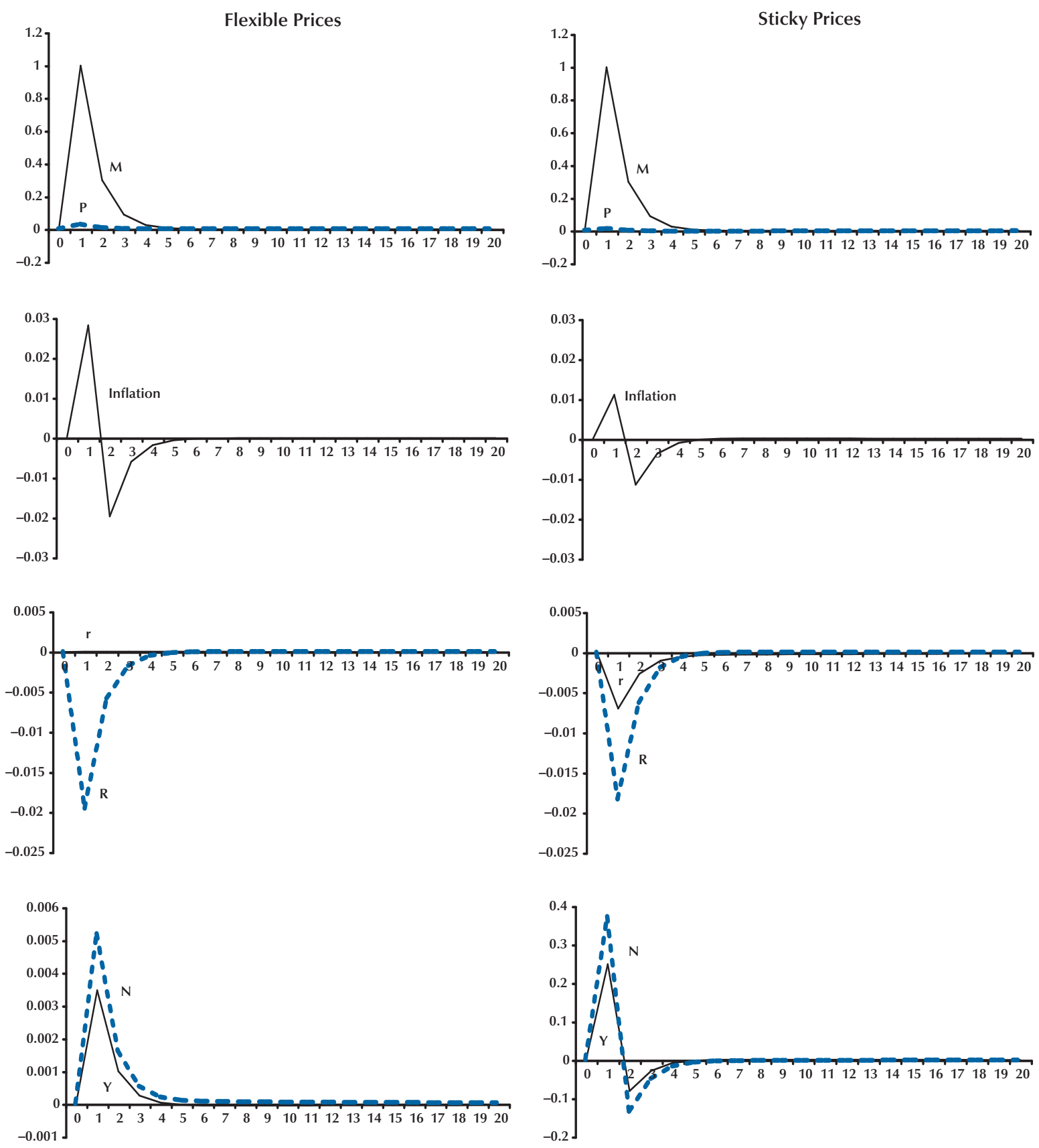
Figure 4

Responses to a Transitory Policy Shock in an Interest Rate Rule
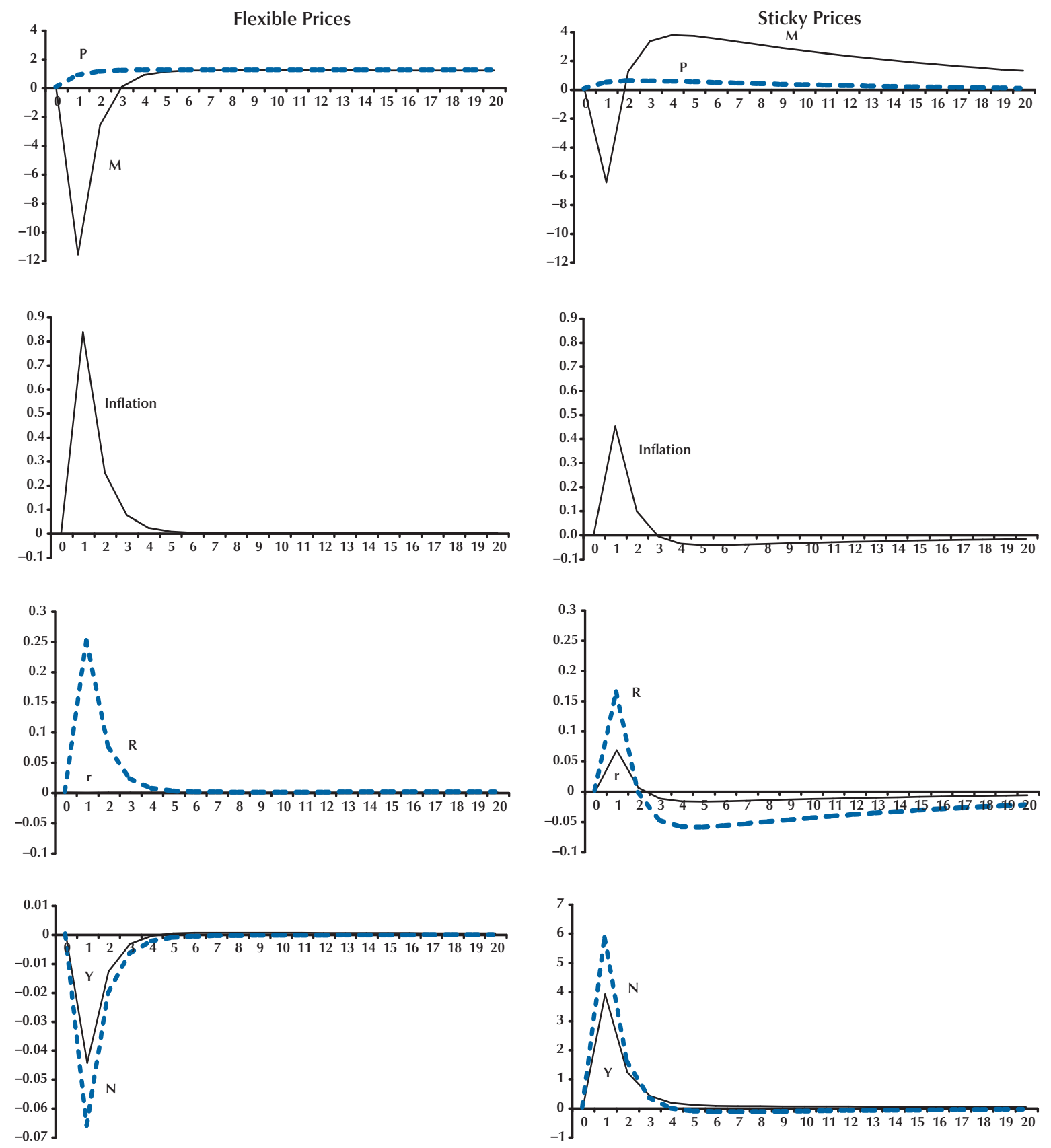
which, in turn, affects the overall response of output. In this regard, the nature of the monetary policy reaction function is quantitatively important for the evolution of real variables only when prices are assumed to be sticky.

The left column of Figure 5 shows the response of the flexible-price, money growth rule economy. This setting serves as a convenient baseline for our comparison, because it most closely approximates an RBC model in which there are no monetary distortions at all. As is typical of this type of shock, the temporary but persistent increase in output that results from the direct effect of the disturbance is enhanced by an increase in the real wage rate and employment. Consequently, the initial rise in output is about 50 percent larger than the direct effect that the technology itself would imply. The increase in factor productivity also engenders an investment response that serves as a propagation mechanism.

However, as widely noted in the RBC literature, this mechanism is rather weak: If there were no persistence in the technology shock, there would be little persistence in output. Because monetary policy does not respond in any way to the shock under a money growth rule, the increase in output implies that the price level falls below trend; the ensuing anticipated disinflation requires an upward adjustment to real money balances, which takes place through a downward jump in the price level. As we saw with shocks to the inflation trend, the shifts in money demand are accommodated by jumps in the price level.

When prices are sticky and the central bank implements a money growth rule, as shown in the right column of Figure 5, the responses of the model to a technology disturbance are dramatically different: The initial downward jump in the price level is only half the size of the jump with flexible prices. Inflation is not persistent in either case. In both cases, the real rate responds as predicted in the benchmark RBC model. The responses of nominal rates are small, but in opposite directions. The most dramatic effects occur in output and hours worked, which decline sharply in the sticky-price model. ${ }^{11}$ There is also

\footnotetext{
${ }^{11}$ Dotsey (1999) shows that changes in interest rate smoothing can
} have large real effects in a sticky-price model. an initial decline in investment (not shown), such that the endogenous propagation channel of capital accumulation is even less quantitatively important.

The key to understanding the responses of this version of the model to productivity shocks is in the nature of the Calvo pricing process: With a majority of firms unable to lower prices in response to the shock, relative demand for their products drops off, moving the firms back along their marginal cost curves. With higher costs and lower final demand, firms dramatically scale back their demand for factors of production until after they have an opportunity to adjust prices. When a larger proportion of firms is assumed to change prices each period, with $\eta=1 / 2$, for example, the initial negative response of output and work does not occur. After prices have adjusted further-after four periods or more in the present calibration-the model economy has adjusted to a trajectory that resembles that of the flexibleprice specification.

The pattern of responses shown in the lower right-hand panel of Figure 5 demonstrates the limitations of a recent influential assertion by Galí (1999). Using a long-run identifying assumption in a vector autoregression model, Galí found that a permanent shock to technology is associated with an initial decline in work effort. From this finding, he argues that sticky prices must play a role in the propagation of technology shocks.

But while our model predicts this type of response when the central bank is following a money growth rule, the response does not occur when policy follows an interest rate rule. As shown in Figure 6, the interest rate rule effectively eliminates the difference between the sticky-price and flexible-price models. The price response is muted by the interest rate rule, compared with the jump that is illustrated in Figure 5. Because interest rate targeting smooths price changes, the gap that develops between the firms that can change prices and those that cannot remains small. The model responses are nearly identical. In other words, the use of an interest rate rule, by eliminating large price-level swings, insulates the real responses of the model from the sticky-price distortions that arise under a money growth rule. 
Figure 5

\section{Responses to a Technology Shock with a Money Growth Rule}
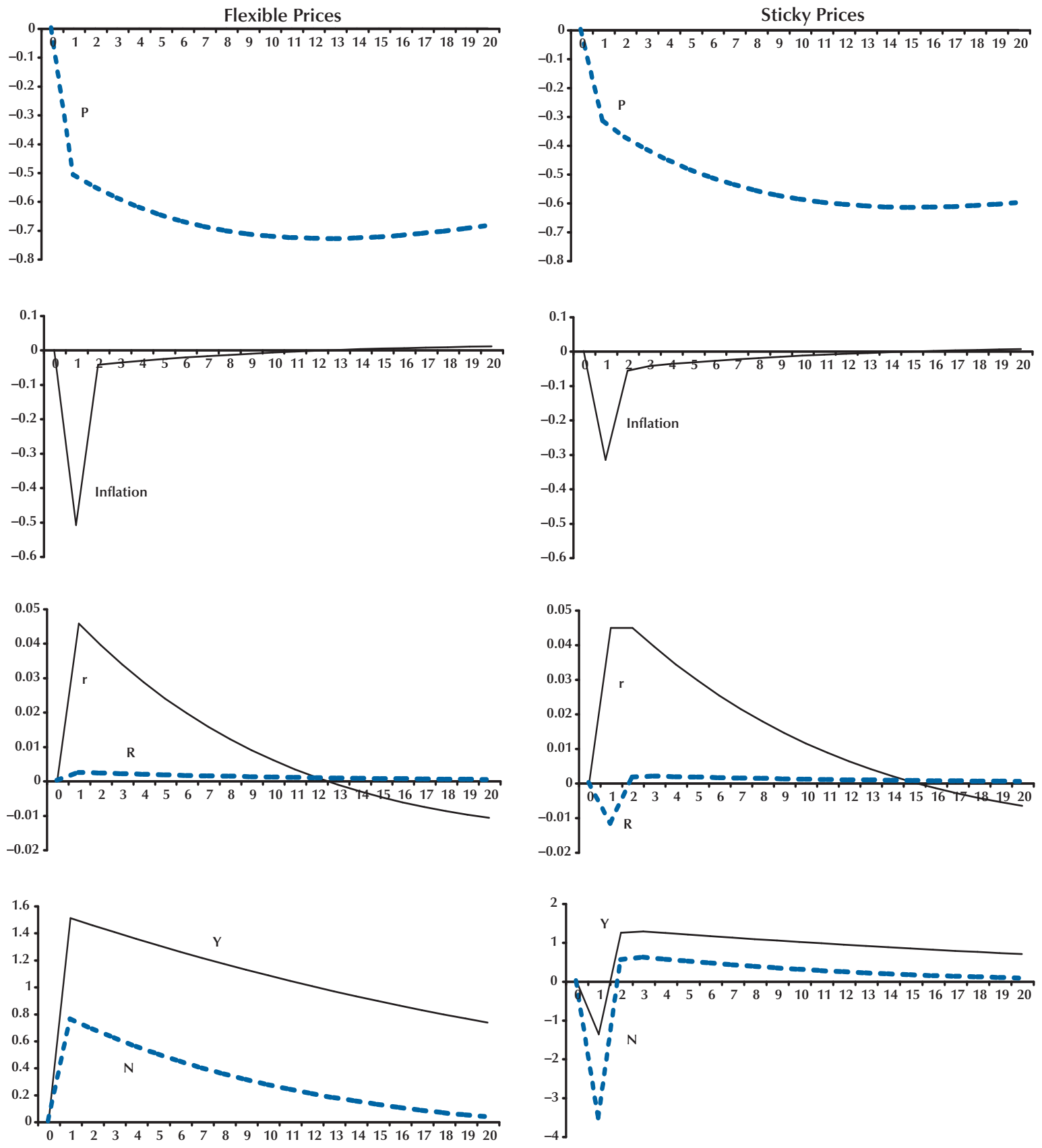


\section{Figure 6}

\section{Responses to a Technology Shock with an Interest Rate Rule}
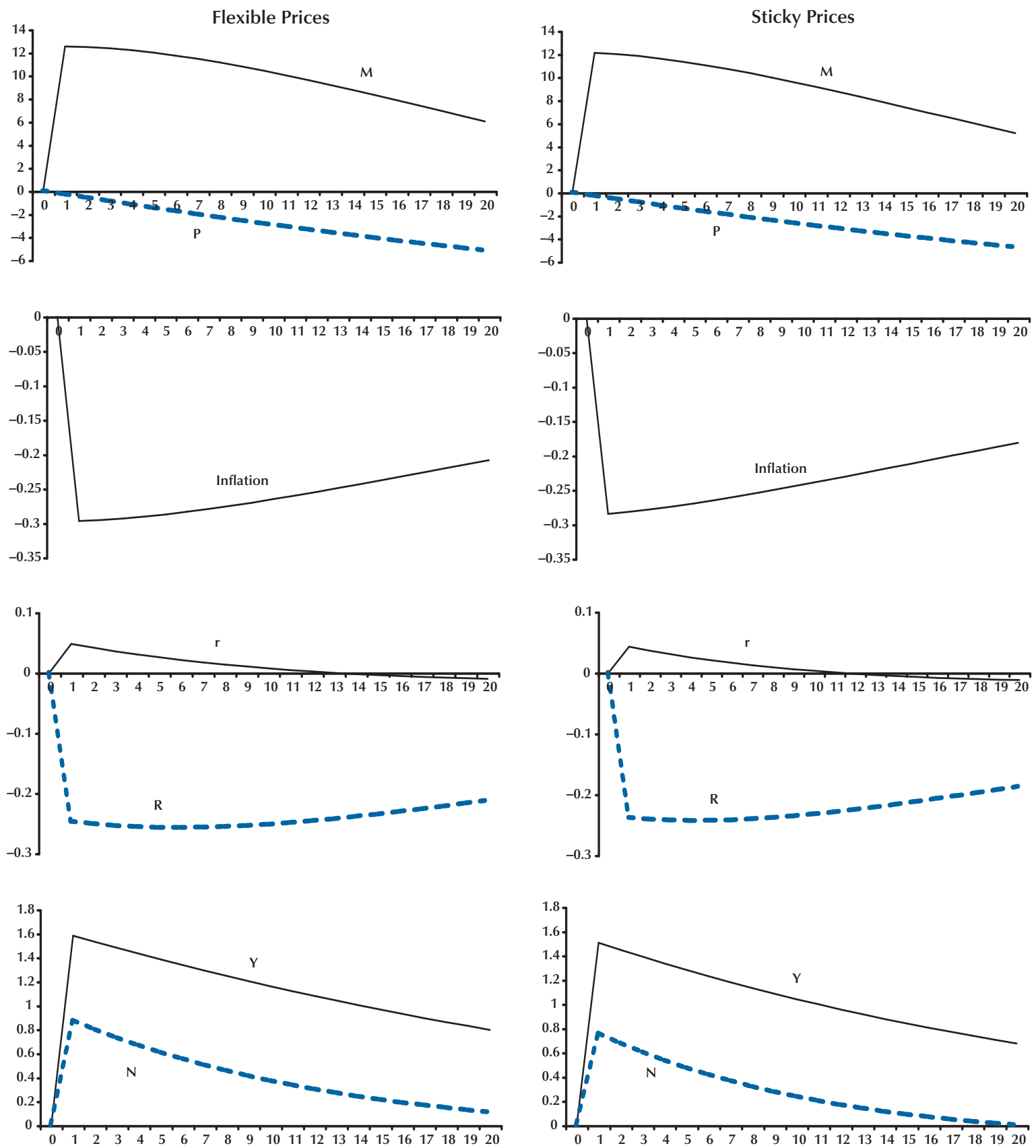


\section{TIME-SERIES PROPERTIES OF MONEY AND PRICES}

This section documents how the time-series properties of money and inflation differ under the alternative monetary policy regimes. ${ }^{12}$ There is a large seasonal element in money but not in prices or interest rates. Mankiw, Miron, and Weil (1987) showed that a strong seasonal component in U.S. interest rates disappeared after the creation of the Federal Reserve in 1913. Barsky and Miron (1989) showed that there are large seasonal components in quantities but not in prices. Both these empirical regularities are consistent with our model of a central bank that uses an interest rate procedure to implement monetary policy.

We begin with a brief look at data for the G7 countries for the period from 1980:Q2 to 1998:Q4. We use data on interest rates, consumer price index (CPI) inflation, and M1 growth, which are not seasonally adjusted. ${ }^{13}$ To calculate the relative persistence in M1 growth and inflation, we calculated the largest root of each series using an augmented Dickey-Fuller equation. The relative volatility is measured by the standard error of the regression. We included five lags of quarterly data to account for the remaining serial correlation and the predictable seasonal component. The results are shown in the top panel of Table 2. The first column reports the standard error of the equation for the augmented Dickey-Fuller regression for CPI inflation. The second column reports the largest root in the CPI regression. The third and fourth columns report the results for M1.

The standard error of the equation for M1 is always larger than that for the CPI. On average it is almost four times larger. For the G7 average, the largest root in CPI inflation is 0.67 and the largest root in M1 is 0.36 . As the results show, there is a large dispersion across countries in the estimates of persistence of M1 growth. ${ }^{14}$

\footnotetext{
12 See Dressler (2003) and Sustek (2004) for models that include both inside and outside money and attempt to account for the dynamic behavior of the monetary aggregates.

${ }^{13}$ We used the International Financial Statistics measure of currency outside banks for the United Kingdom. We did not include 1998 for the United Kingdom because of a large break in the series in 1998:Q2.
}

The bottom panel in Table 2 (Panel B) reports results from our four alternative models under the baseline calibration shown in Table 1. Included are the standard deviations and the first-order autoregressive coefficients for inflation and money growth. We compute statistics for our model economies subject to technology shocks and persistent money growth shocks (with a money growth rule) or persistent inflation target shocks (with the Taylor rule). Those experiments do not include the short-run liquidity shocks. The first two rows of Panel B report the results for the money growth rule and the next two rows report the results for the Taylor rule. The policy rule makes a much bigger difference than does the degree of price flexibility. With a money growth rule, the standard deviation of the inflation rate is always greater than the standard deviation of the money growth rate. The first-order autocorrelation for inflation is near zero. The first-order autocorrelation coefficient for money growth reflects (but is substantially smaller than) the persistence in the shock to the money growth trend.

The model generated data that more closely resemble observed economic data when we use an interest rate rule. Money growth is more variable than inflation. Under both pricing regimes, the first-order autocorrelation of inflation is near 0.7 , but money growth exhibits no autocorrelation. ${ }^{15}$

The last two rows in Panel B show that our results do not depend on persistent shocks to the nominal growth trend. When there are only technology shocks, inflation and money growth are about half as volatile; but the relative variability of money growth and inflation is approximately

\footnotetext{
${ }^{14}$ If we use data on currency and reserves, we find that the money growth rates are much more volatile than when we use M1. The autocorrelation functions of currency and reserve aggregates are dominated by negatively correlated seasonal components. For the United States, seasonally adjusting the data adds persistence to the time series for both money growth and inflation. The adjustment reduces the variability of money growth, but not inflation.

${ }^{15}$ Our models imply that univariate models will underestimate the persistence of shocks to the money growth trend when using data generated under interest rate regimes. For example, Cooley and Hansen $(1989,1995)$ estimate the autocorrelation of monetary shocks to be just 0.5. Using cross-section price and output data and long-run monetary neutrality to achieve identification, Balke and Wynne (2004) estimate that the permanent component in M2 growth is highly persistent-matching broad movements in inflation.
} 


\section{Table 2}

\section{Statistical Properties of Nominal Variables (1980:Q2 to 1998:Q4)}

\section{A. Country results}

\begin{tabular}{|c|c|c|c|c|}
\hline & \multicolumn{2}{|c|}{ CPI } & \multicolumn{2}{|c|}{ M1 } \\
\hline & SEE & Largest root & SEE & Largest root \\
\hline Canada & 0.47 & 0.76 & 2.52 & 0.15 \\
\hline France & 0.34 & 0.82 & 1.22 & 0.69 \\
\hline Germany & 0.45 & 0.71 & 2.12 & -0.33 \\
\hline Italy & 0.41 & 0.91 & 1.67 & 0.54 \\
\hline Japan & 0.50 & 0.43 & 1.37 & 0.44 \\
\hline United Kingdom & 0.62 & 0.64 & 1.39 & -0.68 \\
\hline United States & 0.36 & 0.47 & 1.18 & 0.77 \\
\hline G7 average & 0.45 & 0.68 & 1.64 & 0.36 \\
\hline
\end{tabular}

\section{B. Model results}

\begin{tabular}{|c|c|c|c|c|}
\hline & \multicolumn{2}{|c|}{ CPI } & \multicolumn{2}{|c|}{ M1 } \\
\hline & SD & $\mathrm{AR}(1)$ & SD & $\mathrm{AR}(1)$ \\
\hline \multicolumn{5}{|c|}{ Money growth rule } \\
\hline Sticky prices & 2.22 & 0.03 & 0.51 & 0.70 \\
\hline Flexible prices & 4.36 & -0.07 & 0.51 & 0.69 \\
\hline \multicolumn{5}{|l|}{ Taylor rule } \\
\hline Sticky prices & 0.60 & 0.72 & 10.55 & -0.06 \\
\hline Flexible prices & 0.55 & 0.70 & 9.56 & -0.08 \\
\hline \multicolumn{5}{|c|}{ Technology shocks only } \\
\hline Sticky prices & 0.34 & 0.73 & 5.41 & -0.04 \\
\hline Flexible prices & 0.28 & 0.71 & 4.62 & -0.07 \\
\hline
\end{tabular}

NOTE: An augmented Dickey-Fuller equation with five lags of quarterly data was used to measure the largest root in M1 and CPI growth rates. The standard error of the equation (SEE) was used to measure the volatility in these series. In other cases, we report the standard deviation (SD) and first autocorrelation $(\mathrm{AR}(1))$ in the growth rate series. The baseline calibration was used in the model calculations.

SOURCE: CPI and M1 data come from the OECD Main Economic Indicators. For the United Kingdom, M1 was not available, so we used currency outside banks ending in 1997:Q4. Exact sources and data definitions are listed in Appendix B.

unchanged. With interest rate rules, inflation persistence can be driven by persistent shocks to technology.

The high volatility of the money supply that accompanies interest rate targeting obscures the information content of monetary aggregates. Cooley and LeRoy (1981) document problems that econometricians have faced trying to estimate money demand functions. One of the ironic characteristics of the New Keynesian paradigm is that the model embeds the quantity theory of money as a long-run proposition, but money rarely appears in the policy rule. McCallum (2001) explores the reasons why money does not appear in the policy rule and concludes with support for the notion "that policy analysis in models without money, based on interest rate policy rules, is not fundamentally misguided.”

\section{CONCLUSION}

A comparison of flexible- and sticky-price models with both money growth and interest rate 
policy rules leads to the following conclusions. First, interest rate rules rather than money growth rules can capture the degree of inflation persistence and the relative volatility of the price level observed in the data.

Second, with sticky prices the real effects of transitory policy shocks differ under the different policy rules. When the central bank uses a money growth rule, the real effects are much too large to be plausible in the sticky-price model unless other frictions, such as investment adjustment costs, are also included. But central banks do not use money growth rules, so this counterfactual implication does not seem important. It does, however, suggest a reason why central banks choose to implement monetary policy using an interest rate instrument.

Third, and most importantly for model builders, when shocks are highly persistent, the distinction between monetary policy rules is more important for price dynamics than is the choice of the price-adjustment assumption. The reason for this can be seen in how money demand adjusts under an interest rate rule. In this case, desired price changes are relatively smooth and there is not much difference between flexibleand sticky-price equililbria. A corollary of this result is that the response of nominal variables such as inflation and the money supply are very similar in both flexible- and sticky-price models when the central bank uses an interest rate rule. An important implication of this result is that it will be difficult to use information about firms' actual pricing policies to distinguish between macro theories.

Finally, a central bank's use of interest rate rules obscures the information content of monetary aggregates and leads to subtle problems for econometricians trying to estimate money demand functions or to identify shocks to the trend and cycle components of the money stock. Highly persistent money shocks will be masked by the high-frequency volatility associated with keeping the interest rate relatively constant in the short run.

\section{REFERENCES}

Balke, Nathan S. and Wynne, Mark A. "Sectoral Effects of Monetary Shocks.” Unpublished manuscript, Federal Reserve Bank of Dallas, November 2004.

Barsky, Robert B. and Miron, Jeffrey A. "The Seasonal Cycle and the Business Cycle." Journal of Political Economy, June 1989, 97(3), pp. 503-34.

Calvo, Guillermo A. "Staggered Prices in a Utility Maximizing Framework." Journal of Monetary Economics, September 1983, 12(3), pp. 383-98.

Cho, Jang-Ok, and Cooley, Thomas F. "The Business Cycle with Nominal Contracts.” Economic Theory, 1995, 6(1), pp. 13-33.

Christiano, Lawrence J. and Eichenbaum, Martin. "Liquidity Effects and the Monetary Transmission Mechanism." American Economic Review, 1992, 82(2), pp. 346-53.

Cooley, Thomas F. and Hansen, Gary D. "The Inflation Tax in a Real Business Cycle Model.” American Economic Review, September 1989, 79(4), pp. 733-48.

Cooley, Thomas F. and Hansen, Gary D. "Money and the Business Cycle?" in Thomas F. Cooley, ed., Frontiers of Business Cycle Research. Chap. 7. Princeton: Princeton University Press, 1995, pp. 175-216.

Cooley, Thomas F. and LeRoy, Stephen F. "Identification and Estimation of Money Demand." American Economic Review, December 1981, 71(5), pp. 825-44.

Dittmar, Robert D.; Gavin, William T. and Kydland, Finn E. "Inflation Persistence and Flexible Prices." International Economic Review, February 2005, 46(1), pp. 245-61.

Dotsey, Michael. "The Importance of Systematic Monetary Policy for Economic Activity.” Federal Reserve Bank of Richmond Economic Quarterly, Summer 1999, 85(3), pp. 41-59.

Dressler, Scott. "Monetary Policy Regimes and Causality." Unpublished manuscript, University of Texas, October 2003. 
Erceg, Christopher J. and Levin, Andrew T. "Imperfect Credibility and Inflation Persistence." Journal of Monetary Economics, May 2003, 50(4), pp. 915-44.

Friedman, Milton. The Optimum Quantity of MoneyAnd Other Essays. Chicago: Aldine Publishing, 1969.

Fuerst, Timothy S. "Liquidity, Loanable Funds, and Real Activity." Journal of Monetary Economics, February 1992, 29(1), pp. 3-24.

Galí, Jordi. "Technology, Employment, and the Business Cycle: Do Technology Shocks Explain Aggregate Fluctuations?" American Economic Review, March 1999, 89(1), pp. 249-71.

Goodfriend, Marvin. "Interest Rate Policy and the Inflation Scare Problem: 1979-1992.” Federal Reserve Bank of Richmond Economic Quarterly, Winter 1993, 79(1), pp. 1-24.

Ireland, Peter N. "The Role of Countercyclical Monetary Policy." Journal of Political Economy, August 1996, 104(4), pp. 704-23.

Ireland, Peter N. "Endogenous Money or Sticky Prices?" Journal of Monetary Economics, November 2003, 50(8), pp. 1623-48.

Ireland, Peter N. "Changes in the Federal Reserve's Inflation Target: Causes and Consequences." Unpublished manuscript, Boston College, January 2005.

Keen, Benjamin D. "In Search of the Liquidity Effect in a Modern Monetary Model." Journal of Monetary Economics, October 2004, 51(7), pp. 1467-94.

Kim, Soyoung. "Monetary Policy Rules and Business Cycles." Scandinavian Journal of Economics, 2003, 105(2), pp. 221-45.

Kimball, Miles S. "The Quantitative Analytics of the Basic Neomonetarist Model." Journal of Money, Credit, and Banking, November 1995, 27(4, Part 2), pp. 1241-77.

King, Robert G. and Watson, Mark W. "The Solution of Singular Linear Difference Systems Under
Rational Expectations.” International Economic Review, 1998, 39(4), pp. 1015-26.

King, Robert G. and Watson, Mark W. "System Reduction and Solution Algorithms for Singular Linear Difference Systems Under Rational Expectations." Computational Economics, October 2002, 20(1-2), pp. 57-86.

King, Robert G. and Wolman, Alexander L. "Inflation Targeting in a St. Louis Model of the Twenty-First Century.” Federal Reserve Bank of St. Louis Review, May/June 1996, 78(3), pp. 83-107.

Kozicki, Sharon and Tinsley, Peter A. "Permanent and Transitory Policy Shocks in an Empirical Macro Model with Asymmetric Information.” CFS Working Paper No. 2003/41, Center for Financial Studies, October 2003.

Lucas, Robert E. Jr. "Liquidity and Interest Rates." Journal of Economic Theory, April 1990, 50(2), pp. 237-64.

Lucas, Robert E. Jr. "Inflation and Welfare." Econometrica, March 2000, 68(2), pp. 247-74.

Mankiw, N. Gregory; Miron, Jeffrey A. and Weil, David N. "The Adjustment of Expectations to a Change in Regime: A Study of the Founding of the Federal Reserve." American Economic Review, June 1987, 77(3), pp. 358-74.

McCallum, Bennett T. "Monetary Policy Analysis in Models Without Money." Federal Reserve Bank of St. Louis Review, July/August 2001, 84(4), pp. 145-60.

McCallum, Bennett T. and Nelson, Edward. "An Optimizing IS-LM Specification for Monetary Policy and Business Cycle Analysis." Journal of Money, Credit, and Banking, August 1999, 31(3, Part 1), pp. 296-316.

Rotemberg, Julio J. and Woodford, Michael. “An Optimization-Based Econometric Framework for the Evaluation of Monetary Policy," in Ben S. Bernanke and Julio J. Rotemberg, eds., NBER Macroeconomics Annual 1997. Cambridge, MA: MIT Press, 1997, pp. 297-345. 


\section{Gavin, Keen, Pakko}

Sustek, Roman. "Monetary Aggregates and Structural Shocks.” Unpublished manuscript, Carnegie Mellon University, August 2004.

Taylor, John B. "Discretion versus Policy Rules in Practice.” Carnegie-Rochester Conference Series on Public Policy, 1993, 39, pp. 195-214.
Woodford, Michael. Interest \& Prices. Princeton University Press: Princeton, 2003.

Yun, Tack. "Nominal Price Rigidity, Money Supply Endogeneity, and Business Cycles.” Journal of Monetary Economics, April 1996, 37(2), pp. 345-70.

\section{APPENDIX A}

\section{TECHNICAL NOTES}

This appendix provides detailed information on the sticky- and flexible-price models. It outlines the relevant equations in the model, determines the steady state, and linearizes the model. Furthermore, this appendix provides the necessary information to replicate the simulations of this paper, using the solution methods outlined in King and Watson $(1998,2002)$.

\section{The Equilibrium}

These equations describe the equilibrium for the households' problem. Households are infinitely lived agents who seek to maximize their expected utility from consumption, $C_{t}$, and leisure, $l_{t}$,

$$
E_{0}\left[\sum_{t=0}^{\infty} \beta^{t}\left(\ln \left(c_{t}\right)+\chi \frac{l_{t}^{1-\sigma_{1}}}{1-\sigma_{1}}\right)\right],
$$

subject to the following budget constraint, time constraint, and capital accumulation equation:

$$
\begin{aligned}
& P_{t}\left(c_{t}+i_{t}\right)+M_{t}+B_{t}=P_{t} w_{t} n_{t}+P_{t} q_{t} k_{t}+D_{t}+M_{t-1}+R_{t-1} B_{t-1}+T_{t}, \\
& l_{t}+n_{t}+s_{t}=1,
\end{aligned}
$$

where $B_{t}$ is government bonds, $P_{t}$ is the price level, $i_{t}$ is investment, $M_{t}$ is the nominal money stock, $w_{t}$ is the real wage rate, $n_{t}$ is labor, $q_{t}$ is the rental rate on capital, $k_{t}$ is the capital stock, $D_{t}$ is the firms' profits remitted to the households, $R_{t}$ is the gross nominal interest rate, $T_{t}$ is a transfer from the monetary authority, $\delta$ is the depreciation rate, and $s_{t}$ represents the shopping-time costs of holding money balances,

$$
s_{t}=\zeta\left(P_{t} c_{t} / M_{t}\right)^{\gamma} \text {. }
$$

Utility maximization by the households yields the following first-order conditions for $C_{t}, l_{t}, n_{t}, M_{t}$, $B_{t}, i_{t}$, and $k_{t}$ :

$$
\begin{gathered}
\frac{\partial u}{\partial c_{t}}=P_{t} \lambda_{t}+\gamma\left(s_{t} / c_{t}\right) \tau_{1, t}, \\
\frac{\partial u}{\partial l_{t}}=\tau_{1, t}
\end{gathered}
$$


(A6)

$$
\begin{gathered}
\tau_{1, t}=P_{t} w_{t} \lambda_{t} \\
\lambda_{t}-\gamma\left(s_{t} / M_{t}\right) \tau_{1, t}=\beta E_{t}\left[\lambda_{t+1}\right] \\
\lambda_{t}=\beta E_{t}\left[R_{t} \lambda_{t+1}\right] \\
\lambda_{t} P_{t}=\tau_{2, t}, \text { and } \\
\tau_{2, t}=\beta E_{t}\left[\tau_{2, t+1}(1-\delta)+\lambda_{t+1} P_{t+1} q_{t+1}\right]
\end{gathered}
$$

where $\lambda_{t}, \tau_{1, t}$, and $\tau_{2, t}$ are the Lagrangian multipliers of the budget constraint, time constraint, and the capital accumulation equation, respectively. By substituting (A5) into (A4), (A6), and (A7), the firstorder conditions for $c_{t}, n_{t}$, and $M_{t}$ become

$$
\begin{gathered}
\frac{\partial u}{\partial c_{t}}=P_{t} \lambda_{t}+\gamma\left(s_{t} / c_{t}\right) \frac{\partial u}{\partial l_{t}}, \\
\frac{\partial u}{\partial l_{t}}=P_{t} w_{t} \lambda_{t}, \text { and } \\
\lambda_{t}-\gamma\left(s_{t} / M_{t}\right) \frac{\partial u}{\partial l_{t}}=\beta E_{t}\left[\lambda_{t+1}\right] .
\end{gathered}
$$

By substituting (A9) into (A10), the first-order condition for $k_{t+1}$ becomes

$$
\tau_{2, t}=\beta E_{t}\left[\tau_{2, t+1}(1-\delta)+\tau_{2, t+1} q_{t+1}\right] .
$$

The marginal utilities of $c_{t}$ and $l_{t}$ are

$$
\frac{\partial u}{\partial c_{t}}=\frac{1}{C_{t}} \text { and } \frac{\partial u}{\partial l_{t}}=\chi l_{t}^{-\sigma_{1}}
$$

As a result, the households' problem is described by equations (A1), (A2), (A3), (A8), (A11), (A12), (A13), and (A14).

The next set of equations comes from the firms. The firms are monopolistically competitive producers of output, $y_{j, t}$, according to

$$
y_{j, t}=Z_{t}\left(k_{j, t}\right)^{\alpha}\left(n_{j, t}\right)^{1-\alpha},
$$

where $j$ indicates the number of periods since the firm last adjusted its price, $n_{j, t}$ is firm labor demand, $k_{j, t}$ is firm demand for capital, and $Z_{t}$ is an economywide productivity factor. This productivity factor evolves in the following manner:

$$
\ln \left(Z_{t}\right)=\rho_{Z} \ln \left(Z_{t-1}\right)+\left(1-\rho_{Z}\right) \ln (Z)+\varepsilon_{Z, t},
$$

where $Z$ is the steady-state value of $Z_{t}$ and $\varepsilon_{Z, t}$ is a mean-zero, independently and identically distributed (i.i.d.) shock. Each period, every firm must make two decisions. First, firms determine the costminimizing combination of $k_{j, t}$ and $n_{j, t}$ given their output level, the wage rate, and the rental rate of 


\section{Gavin, Keen, Pakko}

capital services. Second, they make pricing decisions. In particular, the probability a firm can set a new price, $P_{t}^{*}$, is $\eta$ and the probability a firm must charge the price that it last set $j$ periods ago, $P_{t-j}^{*}$, is $(1-\eta)$

Each period, firms seek to minimize their costs,

$$
w_{t} n_{j, t}+q_{t} k_{j, t},
$$

subject to (A15). This cost minimization implies the following two-factor demand equations:

$$
\begin{gathered}
\psi_{t} \alpha Z_{t}\left[n_{j, t} / k_{j, t}\right]^{1-\alpha}=q_{t}, \\
\psi_{t}(1-\alpha) Z_{t}\left[k_{j, t} / n_{j, t}\right]^{\alpha}=w_{t},
\end{gathered}
$$

where $\psi_{t}$ is the Lagrangian multiplier from the production function and accordingly is interpretable as the real marginal cost of output. The market-clearing conditions for capital, $k_{t}$, and labor given the conditional probability of price adjustment $(\eta)$ are

$$
k_{t}=\sum_{j=0}^{\infty} \eta(1-\eta)^{j} k_{j, t} \text { and } n_{t}=\sum_{j=0}^{\infty} \eta(1-\eta)^{j} n_{j, t}
$$

Because the real wage and user cost of capital are economywide costs, the real marginal cost and capital services/labor ratio will be the same for all firms (i.e., $k_{j, t} / n_{j, t}=k_{t} / n_{t}$ ).

The composition of output purchased by households is

$$
y_{t}=\left[\sum_{j=0}^{\infty} \eta(1-\eta)^{j} y_{j, t}^{(\varepsilon-1) / \varepsilon}\right]^{\varepsilon /(\varepsilon-1)},
$$

where

$$
y_{t}=c_{t}+i_{t}
$$

Cost minimization by households yields the following product-demand equation:

$$
y_{j, t}=\left(P_{t-j}^{*} / P\right)^{-\varepsilon} y_{t},
$$

where $P_{t}$ is a nonlinear price index such that

$$
P_{t}=\left[\sum_{j=0}^{\infty} \eta(1-\eta)^{j} P_{t-j}^{*(1-\varepsilon)}\right]^{1 /(1-\varepsilon)} .
$$

Because the probability of price adjustment is constant, (A23) can be reduced to

$$
P_{t}=\left[\eta P_{t}^{*(1-\varepsilon)}+(1-\eta) P_{t-1}^{(1-\varepsilon)}\right]^{1 /(1-\varepsilon)} .
$$

Furthermore, when (A19) is used to aggregate capital and labor over all firms, (A15) becomes

$$
\bar{y}_{t}=\sum_{j=0}^{\infty} \eta(1-\eta)^{j} y_{j, t}=Z_{t}\left(k_{t}\right)^{\alpha}\left(n_{t}\right)^{1-\alpha} .
$$


Recall that the aggregate level of output is (A20). The relationship of $y_{t}$ to $\bar{y}_{t}$ is shown by substituting (A22) into (A25) to get

$$
\bar{y}_{t}=\sum_{j=0}^{\infty} \eta(1-\eta)^{j}\left(P_{t-j}^{*} / P_{t}\right)^{-\varepsilon} y_{t}
$$

To eliminate the infinite number of lags of $P_{t}^{*}$ in (A26), an auxiliary price index is defined as

$$
\bar{P}_{t}=\left[\eta P_{t}^{*}-\varepsilon+(1-\eta) \bar{P}_{t-1}^{-\varepsilon}\right]^{-1 / \varepsilon} \text {. }
$$

Given this price index, (A27) is substituted into (A26) to produce

$$
\bar{y}_{t}=\left(\bar{P}_{t} / P_{t}\right)^{-\varepsilon} y_{t} \text {. }
$$

The fraction $\eta$ of firms that are able to adjust its price seek to maximize the expected value of its profits:

$$
\sum_{j=0}^{\infty} \beta^{j} E_{t}\left[\lambda_{t+j}(1-\eta)^{j}\left[P_{t}^{*} y_{0, t+j}-P_{t+j} w_{t+j} n_{0, t+j}-P_{t+j} q_{t+j} k_{0, t+j}\right]\right]
$$

subject to (A15). Using the factor-demand equations, (A17) and (A18), the production function, (A15), and the firm-demand equation, (A22), the firms' maximization problem, (A29), is rewritten as

$$
\sum_{j=0}^{\infty} \beta^{j} E_{t}\left[\lambda_{t+j}(1-\eta)^{j}\left(P_{t}^{*}-P_{t+j} \psi_{t+j}\right)\left(P_{t}^{*} / P_{t+j}\right)^{-\varepsilon} y_{t+j}\right]
$$

Maximizing (A30) with respect to $P_{t}^{*}$ yields

$$
\sum_{j=0}^{\infty} \beta^{j} E_{t}\left[\lambda_{t+j}(1-\eta)^{j}(1-\varepsilon) P_{t+j}^{\varepsilon} y_{t+j} P_{t}^{*}+\beta^{j} \lambda_{t+j} \eta(1-\eta)^{j} \varepsilon P_{t+j}^{1+\varepsilon} \psi_{t+j} y_{t+j}\right]=0 .
$$

Thus, the profit-maximizing price is

$$
P_{t}^{*}=V_{C, t} / V_{R, t},
$$

where

$$
V_{R, t}=\sum_{j=0}^{\infty} \beta^{j} E_{t}\left[(1-\eta)^{j}(\varepsilon-1) \lambda_{t+j} P_{t+j}^{\varepsilon} y_{t+j}\right] \text { and } V_{C, t}=\sum_{j=0}^{\infty} \beta^{j} E_{t}\left[(1-\eta)^{j} \varepsilon \lambda_{t+j} P_{t+j}^{1+\varepsilon} \psi_{t+j} y_{t+j}\right]
$$

Furthermore, the evolution of $V_{R, t}$ and $V_{C, t}$ can be written in the following manner:

$$
\begin{aligned}
& V_{R, t}=(\varepsilon-1) \lambda_{t} P_{t}^{\varepsilon} y_{t}+\beta(1-\eta) E_{t}\left[V_{R, t+1}\right] \text { and } \\
& V_{C, t}=\varepsilon \lambda_{t} P_{t}^{1+\varepsilon} \psi_{t} y_{t}+\beta(1-\eta) E_{t}\left[V_{C, t+1}\right] .
\end{aligned}
$$

Therefore, the firms' problem is summarized by (A16), (A17), (A18), (A21), (A24), (A25), (A27), (A28), (A31), (A32), and (A33).

\section{The Steady State}

These are the steady-state equations for the households. To begin, the steady-state equations for the time constraint, (A1), the capital accumulation equation, (A2), and the shopping-time costs, (A3), are 


$$
\begin{aligned}
& n+l+s=1, \\
& i / k=\delta k, \text { and } \\
& s=\xi(P C / M)^{\gamma} .
\end{aligned}
$$

The steady-state first-order conditions for the households' problem, (A8), (A11), (A12), (A13), and (A14), are

$$
\begin{aligned}
& \pi=\beta R, \\
& 1 / c=P \lambda+\gamma(s / c) \chi I^{-\sigma_{1}}, \\
& \chi I^{-\sigma_{1}}=P W \lambda, \\
& \lambda-\gamma(s / M) \chi I^{-\sigma_{1}}=\beta \lambda / \pi, \text { and } \\
& 1=\beta[(1-\delta)+q] .
\end{aligned}
$$

Next are the steady-state equations for the firms. The first two equations are the steady states of the factor-demand equations, (A17) and (A18):

$$
\begin{aligned}
& \psi \alpha Z\left[n_{j} / k_{j}\right]^{1-\alpha}=q \text { and } \\
& \psi(1-\alpha) Z\left[k_{j} / n_{j}\right]^{\alpha}=w .
\end{aligned}
$$

Recall that $k_{j, t} / n_{j, t}=k_{t} / n_{t}$, so that $k_{j} / n_{j}=k / n$ in the steady state. The steady-state aggregate production function, (A25), is

$$
\bar{y}=Z(k)^{\alpha}(n)^{1-\alpha} .
$$

The steady-state relationship between $y$ and $\bar{y}$ from (A28) is

$$
\bar{y}=(\bar{P} / P)^{-\varepsilon} y,
$$

where the steady-state value of $\bar{P}$ from (A25) is

$$
\bar{P}=\left[\eta P^{*}-\varepsilon+(1-\eta) \pi^{\varepsilon} \bar{P}^{-\varepsilon}\right]^{-1 / \varepsilon},
$$

and where $\pi$ is the steady-state inflation rate. The steady-state profit-maximizing price from (A31) is

$$
P^{*}=V_{C} / V_{R},
$$

where the steady-state values of $V_{R}$ and $V_{C}$ in (A32) and (A33) are

$$
\begin{aligned}
& V_{R}=(\varepsilon-1) \lambda P^{\varepsilon} y+\beta(1-\eta) \pi^{\varepsilon-1} V_{R} \text { and } \\
& V_{C}=\varepsilon \lambda P^{1+\varepsilon} \psi y+\beta(1-\eta) \pi^{\varepsilon} V_{C} .
\end{aligned}
$$

Finally, the steady-state identity equations for $y$ and $P$ from (A21) and (A24) are

$$
y=c+i \text { and } P=\left[\eta P^{*(1-\varepsilon)}+(1-\eta)(P / \pi)^{(1-\varepsilon)}\right]^{1 /(1-\varepsilon)} .
$$

\section{Linearization Around the Steady State}

This section linearizes the model around its steady state. A hat is used to signify percent deviation from the steady state. Thus, $\hat{n}_{t}$ is the percent deviation of labor from its steady state. 
Beginning with households, the linearized equations for the time constraint, (A1), the capital accumulation equation, (A2), and the shopping-time costs, (A3), are

$$
\begin{aligned}
& \hat{l}_{t}+n \hat{n}_{t}+s \hat{s}_{t}=0, \\
& \hat{k}_{t+1}=(i / k) \hat{i}_{t}+(1-\delta) \hat{k}_{t}, \text { and } \\
& \hat{P}_{t}+\hat{c}_{t}-\hat{M}_{t}-(1 / \gamma) \hat{s}_{t}=0 .
\end{aligned}
$$

The linearized first-order conditions for the households' problem, (A8), (A11), (A12), (A13), and (A14), are

$$
\begin{gathered}
\hat{\lambda}_{t}=\hat{R}_{t}+E_{t}\left[\hat{\lambda}_{t+1}\right], \\
-(1 / c) \hat{c}_{t}=P \lambda\left(\hat{\lambda}_{t}+\hat{P}_{t}\right)+\gamma(s / c) \chi I^{-\sigma_{1}}\left(\hat{s}_{t}-\hat{c}_{t}-\sigma_{1} \hat{l}_{t}\right), \\
\hat{\lambda}_{t}+\hat{P}_{t}+\hat{w}_{t}+\sigma_{1} \hat{l}_{t}=0, \\
\lambda \hat{\lambda}_{t}-\gamma(s / M) \chi I^{-\sigma_{1}}\left(\hat{s}_{t}-\hat{M}_{t}-\sigma_{1} \hat{l}_{t}\right)=\lambda(\beta / \pi) E_{t}\left[\hat{\lambda}_{t+1}\right], \text { and } \\
\hat{\tau}_{2, t}=E_{t}\left[\hat{\tau}_{2, t+1}+\beta q \hat{q}_{t+1}\right] .
\end{gathered}
$$

Now, on the firm side, the linearized factor-demand equations for capital and labor, (A17) and (A18), are

$$
\begin{aligned}
& \hat{\psi}_{t}+\hat{Z}_{t}+(1-\alpha)\left(\hat{n}_{t}-\hat{k}_{t}\right)=\hat{q}_{t} \text { and } \\
& \hat{\psi}_{t}+\hat{Z}_{t}+\alpha\left(\hat{k}_{t}-\hat{n}_{t}\right)=\hat{w}_{t} .
\end{aligned}
$$

The linearizations of (A25) and (A28) are as follows:

$$
\begin{aligned}
& \hat{\bar{y}}_{t}=\hat{Z}_{t}+\alpha \hat{k}_{t}+(1-\alpha) \hat{n}_{t}, \text { and } \\
& \hat{\bar{y}}_{t}=\varepsilon\left[\hat{P}_{t}-\hat{\bar{P}}_{t}\right]+\hat{y}_{t},
\end{aligned}
$$

where the linearization of (A27) is

$$
\hat{\bar{P}}_{t}=\eta\left[P^{*} / \bar{P}\right]^{(-\varepsilon)} \hat{P}_{t}^{*}+(1-\eta) \mu^{\varepsilon} \hat{\bar{P}}_{t-1} .
$$

The linearized profit-maximizing price from (A31) is

$$
\hat{\bar{P}}_{t}^{*}=\hat{V}_{C, t}-\hat{V}_{R, t},
$$

where the linearized values of $V_{R}$ and $V_{C}$ in (A32) and (A33) are

$$
\begin{aligned}
& \hat{V}_{R, t}=\frac{(\varepsilon-1) \lambda P^{\varepsilon} y}{V_{R}}\left(\hat{\lambda}_{t}+\varepsilon \hat{P}_{t}+\hat{y}_{t}\right)+\beta(1-\eta) \pi^{\varepsilon-1} E_{t}\left[\hat{V}_{R, t+1}\right] \text { and } \\
& \hat{V}_{C, t}=\frac{\varepsilon \lambda P^{1+\varepsilon} \psi y}{V_{C}}\left[\hat{\lambda}_{t}+(1+\varepsilon) \hat{P}_{t}+\hat{y}_{t}+\hat{\psi}_{t}\right]+\beta(1-\eta) \pi^{\varepsilon} E_{t}\left[\hat{V}_{C, t+1}\right] .
\end{aligned}
$$

The linearized versions of the identity equations for aggregate output and the price level, (A21) and (A24), are 


$$
\begin{gathered}
\hat{y}_{t}=\frac{c}{y} \hat{c}_{t}+\frac{i}{y} \hat{i}_{t} \text { and } \\
\hat{P}_{t}=\eta\left(P^{*} / P\right)^{(1-\varepsilon)} \hat{P}_{t}^{*}+(1-\eta) \pi^{(\varepsilon-1)} \hat{P}_{t-1} .
\end{gathered}
$$

The monetary authority's policy instrument is either money or the nominal interest rate. When money is the instrument, the linearized policy rule is

$$
\Delta \hat{M}_{t}=\hat{\mu}_{t}^{*}+\left(v_{t}-v_{t-1}\right),
$$

where $\mu_{t}^{*}$ is the target money growth rate, which follows an AR(1) process, $\hat{\mu}_{t}^{*}=\rho_{\mu} \hat{\mu}_{t-1}^{*}+\varepsilon_{\mu t}$; and $v_{t}$ is a transitory shock to the money growth rule, which also follows an AR(1) process, $v_{t}=\rho_{u} v_{t-1}+\varepsilon_{v t}$. Both error terms, $\varepsilon_{\mu t}$ and $\varepsilon_{v t}$, are mean-zero, i.i.d. shocks.

When the nominal interest rate is the instrument, the linearized policy rule is

$$
\hat{R}_{t}=\hat{\pi}_{t}+\theta_{\pi}\left(\hat{\pi}_{t}-\hat{\pi}_{t}^{*}\right)+\theta_{y} \hat{y}_{t}+u_{t},
$$

where $\hat{\pi}_{t}=\hat{P}_{t}-\hat{P}_{t-1} ; \hat{\pi}_{t}^{*}$ is the target inflation rate, which follows an AR(1) process, $\hat{\pi}_{t}^{*}=\rho_{\pi} \hat{\pi}_{t-1}^{*}+\varepsilon_{\pi t}$; and $u_{t}$ is a shock to the interest rate rule, which also follows an AR(1) process, $u_{t}=\rho_{u} u_{t-1}+\varepsilon_{u t}$. Both error terms, $\varepsilon_{\pi t}$ and $\varepsilon_{u t}$, are mean-zero, i.i.d. shocks.

\section{APPENDIX B}

\section{DATA}

The data set contains quarterly time series for the G7 countries on the CPI and a narrow money measure, usually M1. All the series are available from 1980:Q1 through 1998:Q4. We could not get M1 for the United Kingdom, so we used a measure of currency. For this series, we excluded the 1998 data because there was a break in the series in the second quarter. All of the series are from the Organisation for Economic Co-operation and Development's (OECD) Main Economic Indicators database or the International Financial Statistics database. The data are not seasonally adjusted, and the quarterly figures are computed as averages of monthly data. The data were retrieved in mid-October 2004 from the Haver database, and Haver mnemonics are listed for each variable.

Canada: money supply (M1) is c156fm1n@oecdmei; CPI inflation is c156czn@oecdmei.

France: money supply (M1) is c132fm1n@oecdmei; CPI inflation is c132czn@oecdmei.

Germany: money supply (M1) is c134fm1n@oecdmei; CPI inflation is c134czn@oecdmei.

Italy: money supply (M1) is c136fm1n@oecdmei; CPI inflation is c136czn@oecdmei.

Japan: money supply (M1) is c158fm1n@oecdmei; CPI inflation is c158czn@oecdmei.

United Kingdom: money supply (currency outside of banks) is c112mlc@ifs; CPI inflation is c112czn@oecdmei.

United States: money supply (M1) is c111fm1n@oecdmei; CPI inflation is c111czn@oecdmei. 